\title{
圧電素子と電子回路を用いた二重吸振器による受動制振*
}

\author{
山田啓介*1, 松久 寛*2, 宇津野秀夫*3
}

\section{Passive Vibration Suppression by a Dual Electrical Vibration Absorber Using Piezoelectric Elements and Analog Circuits}

\author{
Keisuke YAMADA*4, Hiroshi MATSUHISA and Hideo UTSUNO
}

\footnotetext{
${ }^{* 4}$ Department of Mechanical Engineering and Science, Kyoto University, Yoshida-Honmachi, Sakyo-ku, Kyoto-shi, Kyoto, 606-8501 Japan
}

\begin{abstract}
This paper proposes new methods which improve the robustness and the performance of the passive vibration suppression by a dual electrical absorber using piezoelectric elements and analog circuits. Two types of methods which use two inductances were proposed in this paper. Because the electrical systems of new methods have two resonance frequencies, those new methods could improve the performance and the robustness by choosing the inductances and resistances of the circuit. Optimum values of the circuit were derived for both cases with and without the variation of the stiffness of the main system. The effectiveness of new methods and the optimum values of the circuit were verified by calculation and experiment.
\end{abstract}

Key Words : Piezo-Element, Flexible Structure, Dynamic Absorber, Smart Structure, Vibration Control

\section{1. 粕 言}

圧電素子を用いてはりや平板等の屈曲振動を抑制す る方法が注目され，多数の研究が行われている. 圧電 素子を用いた制振は機械式動吸振器やアクティブマス ダンパを用いる制振に比べて，必要なスペースが小さ く，圧電素子自体の大きさの割に得られる制御力が大 きいためである．圧電素子を用いた制振には，外部か ら圧電素子に制御電圧を加える能動制振 ${ }^{(1),(2)}$ とインダ クタンスや抵抗等を圧電素子に接続することによって 機械式動吸振器のようにふるまわせる受動制振 ${ }^{(3)}$ (7)が ある.

能動制振では制御電圧を大きくすることにより高い 制振性能を実現でき, 制御器の設計によってはロバス ト性を高めることができるが，常にその発振の可能性 が問題となる．また，デジタルのコントローラを用い る場合は振動数の高い振動モ一ドは制御できず，装置

* 原稿受付 2006 年 10 月 26 日.

*1 正員, 京都大学大学院工学研究科, 日本学術振興会特別研究 員 PD(\$606-8501 京都市左京区吉田本町).

*2 正員, フェロー, 京都大学大学院工学研究科.

*3 正員, 京都大学大学院工学研究科.

E-mail : keisu@t01.mbox.media.kyoto-u.ac.jp
の価格が高くなる. そこで，受動的な手法で，高い制 振性能とロバスト性を実現する必要がある. 圧電素子 を用いた受動制振の中では LR 回路を用いた手法の制 振性能が比較的高いが，それでも能動制振と同等の制 振性能を実現するためには圧電素子の数を增やす必要 がある. また，回路内の電気共振によって主系の振動 を抑えるので, 主系の固有振動数が変化する場合には 制振性能が低下する問題もある. 一方, この LR 回路 を用いた制振手法と制振の原理が類似している機械式 動吸振器では, 制振性能とロバス卜性の問題を多重動 吸振器で解決できるという知見が得られている(8), (9). そこで, 本研究では機械式の多重動吸振器に相当する 回路を提案する. 多重動吸振器の性能とロバスト性は 動吸振器系の自由度を増やすほど向上するが, 同時に 装置の最適調整が困難になるので, ここでは二重動吸 振器に限定する. 機械式の二重動吸振器には並列型(8) と直列型(9)があるが，本論文ではその両方に相当する モデルを示す. それぞれのモデルにおいて，主系の剛 性の変化を考虑する場合と考虑しない場合の回路の最 適調整式を求め, 数值計算と実験で, 本手法と最適調 整式の有効性を検証する. 


\section{2. 二重吸振器モデルと最䔔調整式}

機械式の二重動吸振器は, 合計の質量が等しい一重 動吸振器よりも制振性能が高く, 動吸振器系の二つの 固有振動数を調整することでロバスト性を向上させる ことができる. この二重動吸振器には並列型(8) と直列 型(9があり, 直列型の方が制振性能に優れるが, 並列 型は動吸振器系の二つの固有振動数の調整が独立であ るため最適調整は容易である.このようにそれぞれが 利点を持つため, 本論文では圧電素子と電子回路を用 いた受動制振でその両方に相当するモデルを提案する. また, 機械式の二重動吸振器では, 主系がモデル化誤 差を持たない場合の動吸振器系の最適調整式（以下， ノミナル最適調整式と称す) と, 主系がモデル化誤差 を持つ，ここでは特に主系の剛性が変化する場合の最 適調整式 (以下， ロバス卜最適調整式と称す）が求め られている(8), (9). 機械式の装置の場合, 動吸振器系の 総質量一定の条件の下でこれらの最適調整式は求めら れるが，圧電素子を用いた装置の場合は圧電素子の等 価剛性が一定という条件になり, 前提となる条件が異 なる，そこで，本論文では提案する二つの電気式二重 吸振器モデルの最適調整式も新たに求める.

Piezoelectric element 2

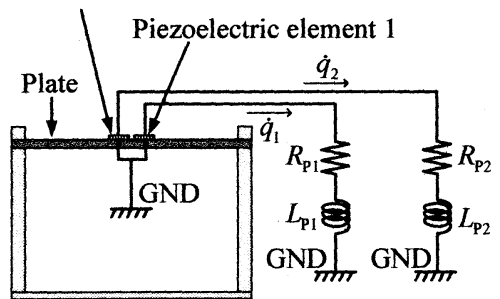

Fig. 1 Model of a dual and parallel electrical vibration absorber.

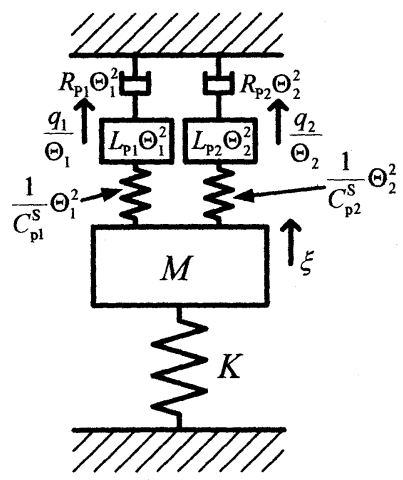

Fig. 2 Equivalent mechanical model for the model of the dual and parallel electrical vibration absorber.
$2 \cdot 1$ 並列二重吸撮器のモデル 図 1 に圧電素子 と電子回路を用いた並列二重吸振器のモデルを示す. 圧電素子は二組に分けて使用し，それぞれの圧電素子 に LR 回路を接続することで，それぞれが電気式の一 重吸振器になる. 図 2 にこのモデルの等価機械モデル を示す ${ }^{(10)}$. 図 1,2 中の記号は次項で説明する. 等価機 械モデルは機械式の並列二重動吸振器のモデルと少し 異なるが，主系に二つの一重動吸振器を並列に設置し たモデルであり，機械式の並列二重動吸振器に類似し た効果が得られる.

2.1.1 支配方程式一般に吸振器は主系の減衰 が小さい場合に用いられるので，ここでは主系の減衰 は無視する.この手法で抑えられる振動モ一ドは単一 であり, 制振性能をその共振の大きさで評価するため, 他の振動モードは近似的に無視できる. 図 1 に示した 並列二重吸振器のモデルの支配方程式は

$$
\begin{aligned}
& M \ddot{\xi}+K \xi+\Theta_{1}\left(\frac{\Theta_{1}}{\left.C_{\mathrm{p} 1}^{\mathrm{s}} \xi-\frac{1}{C_{\mathrm{p} 1}^{\mathrm{s}}} q_{1}\right)}\right. \\
& +\Theta_{2}\left(\frac{\Theta_{2}}{C_{\mathrm{p} 2}^{\mathrm{s}}} \xi-\frac{1}{C_{\mathrm{p} 2}^{\mathrm{s}}} q_{2}\right)=Q P_{\mathrm{f}} \\
& L_{\mathrm{p} 1} \ddot{q}_{1}+R_{\mathrm{p} 1} \dot{q}_{1}+\frac{1}{C_{\mathrm{p} 1}^{\mathrm{s}}} q_{1}=\frac{\Theta_{1}}{C_{\mathrm{p} 1}^{\mathrm{s}}} \xi \\
& L_{\mathrm{p} 2} \ddot{q}_{2}+R_{\mathrm{p} 2} \dot{q}_{2}+\frac{1}{C_{\mathrm{p} 2}^{\mathrm{s}}} q_{2}=\frac{\Theta_{2}}{C_{\mathrm{p} 2}^{\mathrm{s}}} \xi
\end{aligned}
$$

である.ここで， $M$ はモード質量， $K$ はモート風性， $\Theta$ はモード電気機械結合係数, $C_{\mathrm{p}}^{\mathrm{s}}$ は圧電素子のキャ パシタンス, $Q$ はモード外力影響係数，Lはインダク タンス, $R$ は抵抗， $\xi$ はモード変位， $q$ は電荷， $P_{\mathrm{f}}$ は 平板に加わる等分布荷重である. 下付きの数字は二つ の圧電素子をそれぞれ示す.式(1)-(3)より無次元化した コンプライアンスは

$$
\begin{aligned}
& \frac{\xi}{\xi_{\mathrm{st}}}=\frac{1}{-g^{2}+1+\beta_{1}\left(1-G_{\mathrm{A}}\right)+\beta_{2}\left(1-G_{\mathrm{B}}\right)} \\
& G_{\mathrm{A}}=\frac{q_{1}}{\Theta_{1} \xi}=\frac{f_{\mathrm{A} 1}^{2}}{-g^{2}+f_{\mathrm{A} 1}^{2}+2 j \zeta_{1} f_{\mathrm{A} 1} g} \\
& G_{\mathrm{B}}=\frac{q_{2}}{\Theta_{2} \xi}=\frac{f_{\mathrm{A} 2}^{2}}{-g^{2}+f_{\mathrm{A} 2}^{2}+2 j \zeta_{2} f_{\mathrm{A} 2} g} \\
& \xi_{\mathrm{st}}=\frac{Q P_{\mathrm{f}}}{K}, g=\frac{\omega}{\Omega}, \Omega=\sqrt{\frac{K}{M}}, \omega_{\mathrm{A} 1}=\sqrt{\frac{1}{L_{\mathrm{P} 1} C_{\mathrm{p} 1}^{\mathrm{S}}}} \\
& \omega_{\mathrm{A} 2}=\sqrt{\frac{1}{L_{\mathrm{P} 2} C_{\mathrm{p} 2}^{\mathrm{S}}}, \quad \beta_{1}=\frac{\Theta_{1}^{2}}{K C_{\mathrm{p} 1}^{\mathrm{s}}}, \quad \beta_{2}}=\frac{\Theta_{2}^{2}}{K C_{\mathrm{p} 2}^{\mathrm{s}}} \\
& f_{\mathrm{A} 1}=\frac{\omega_{\mathrm{A} 1}}{\Omega}, \quad f_{\mathrm{A} 2}=\frac{\omega_{\mathrm{A} 2}}{\Omega}
\end{aligned}
$$




$$
\zeta_{1}=\frac{R_{\mathrm{p} 1}}{2} \sqrt{\frac{C_{\mathrm{p} 1}^{\mathrm{s}}}{L_{\mathrm{p} 1}}}, \quad \zeta_{2}=\frac{R_{\mathrm{p} 2}}{2} \sqrt{\frac{C_{\mathrm{p} 2}^{\mathrm{s}}}{L_{\mathrm{p} 2}}}
$$

となる.ここで, $\omega$ は加振振動数である. また, 二組 の圧電素子をまとめて一組にした場合の圧電素子の等 価岡性比 $\beta$ と, まとめる前の二組の圧電素子の等価剛 性比 $\beta_{1}, \beta_{2}$ との間には，並列のバランスを取れば $\beta=\beta_{1}+\beta_{2}$ という関係がある.

2:1.2 ノミナル最薏調整式 一重吸振器の場合 は定点理論を用いて回路の最適調整式を導出すること ができるが, 二重吸振器の場合は式(4)(6)のようにコン プライアンスが複雑になり，理論的に最適調整式を導 くことは困難である，そこで，機械式の二重動吸振器 では, 数值最適化手法を用いて, 主系の最大振幅を最 小にする条件で動吸振器の最適調整が行われる. また, 動吸振器の総質量比を実用的な範用で変化させて固有 振動数比や減衰比の最適值をグラフ化し，それらを近 似式で表した報告もある(8). 本論文では最適調整式の 制約条件を確認し，その後，近似的に最適調整式を求 める.

式(4)-(6)より $f_{\mathrm{A} 1}, f_{\mathrm{A} 2}, \zeta_{1}, \zeta_{2}$ の四つの最適調整 式を求める必要がある.ここで, 式(1)-(3)より支配方程 式は線形であるので, これらの最適調整式は二つの圧 電素子の等価剛性比 $\beta_{1}, \beta_{2}$ のみによって表される. ここで，二組の圧電素子の等価岡性比の比は機械式の 並列二重動吸振器の質量比の比と同様に $1: 1$ がほぼ最 適であるので, ここでは諸元の等しい圧電素子とする. すなわち， $\beta_{1}=\beta_{2}=\beta / 2$ とする. 圧電素子の等価剛 性比の比を定めると，まとめて一組にした場合の圧電 素子の等価岡性比 $\beta$ を用いて最適調整式を表すこと ができる. 図 3 に数值最適化手法で求めた $f_{\mathrm{A} 1}, f_{\mathrm{A} 2}$, $\zeta_{1}, \zeta_{2}$ の最適值を示寸. ここでは等価剛性比 $\beta$ を 0.0004 から 0.04 まで変化させた. 図 4 に例として $\beta=0.0004,0.004,0.04$ の時にこれらの最適値を 用いて求めたコンプライアンスを示す。この結果より 図3に示した最適值が有効であることが分かる. $f_{\mathrm{A} 1}$, $f_{\mathrm{A} 2}, \zeta_{1}, \zeta_{2}$ の最適值を近似式で表すと

$$
\begin{aligned}
& f_{\mathrm{A} 1}=\sqrt{1+0.591 \sqrt{\beta}+0.679 \beta} \\
& f_{\mathrm{A} 2}=\sqrt{1-0.592 \sqrt{\beta}+0.590 \beta} \\
& \zeta_{1}=\sqrt{0.160 \beta-0.216 \beta^{2}} \\
& \zeta_{2}=\sqrt{0.173 \beta+0.300 \beta^{2}}
\end{aligned}
$$

となった. 図 3 より二つの一重吸振器の固有振動数は 主系の固有振動数 $\Omega$ の前後に分かれ，主系の固有振動 数との差はほぼ1:1である. なお, 近似式(7)-(10)は決 定係数がほぼ 1 であり, 図3に示したグラフとよく一
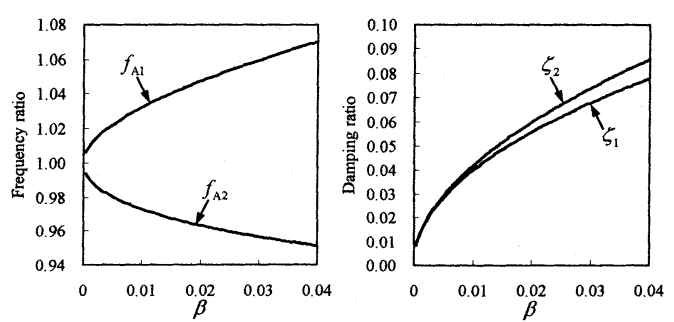

Fig. 3 Optimum frequency ratios and damping ratios for the dual and parallel electrical vibration absorber.

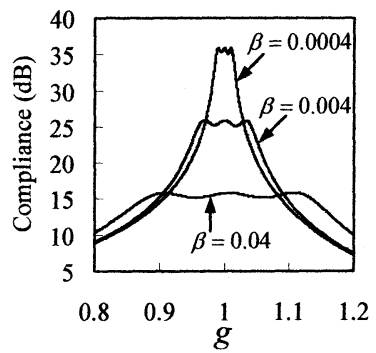

Fig. 4 Calculated results of compliance using the dual and parallel electrical vibration absorber.

致する. 回路の最適值は式(7)-(10)より求めることがで きる.

2.1.3 ロバスト最薏調整式 ここでは主系の凪 性が変化する場合を想定したロバスト最適調整式を求 める. このロバスト最適調整式は前項と同様にまとめ て一組にした圧電素子の等価剛性比 $\beta$ を用いて表す ことができるが, 主系の剛性の変化をどの程度に見積 もるかによって結果が異なる。ここでは代表として $\pm 10 \%, \pm 20 \%$ の剛性の変化を想定した場合の最適調 整式を示す.

主系の剛性の変化率を $\pm 10 \%$ と想定した場合は

$$
\begin{aligned}
& f_{\mathrm{A} 1}=\sqrt{1.05+0.511 \sqrt{\beta}+1.16 \beta} \\
& f_{\mathrm{A} 2}=\sqrt{0.943-0.321 \sqrt{\beta}+0.111 \beta} \\
& \zeta_{1}=\sqrt{0.000450+0.182 \beta-0.781 \beta^{2}} \\
& \zeta_{2}=\sqrt{0.000826+0.207 \beta+0.445 \beta^{2}}
\end{aligned}
$$

となった. また，主系の岡性の変化率を $\pm 20 \%$ と想定 した場合は

$$
\begin{aligned}
& f_{\mathrm{A} 1}=\sqrt{1.13+0.260 \sqrt{\beta}+2.12 \beta} \\
& f_{\mathrm{A} 2}=\sqrt{0.881-0.0966 \sqrt{\beta}-0.0997 \beta} \\
& \zeta_{1}=\sqrt{0.00157+0.172 \beta-0.383 \beta^{2}} \\
& \zeta_{2}=\sqrt{0.00371+0.242 \beta-0.0368 \beta^{2}}
\end{aligned}
$$

であった. 近似式(11)-(18)も決定係数がほぼ 1 であった. なお， $\beta$ を定数とすると $f_{\mathrm{A} 1}, f_{\mathrm{A} 2}, \zeta_{1}, \zeta_{2}$ の最適値 
はいずれも剛性の変化率を変数とした二次関数上に乗 るので, 任意の変化率での最適值が必要な場合はその 性質を利用して式(7)-(18)より求めればよい。

本論文では主系の剛性が変化する場合を対象とした ロバスト最適調整式を求めたが, 圧電素子の特性が変 化する場合もある. その場合も, 数値最適化手法を用 いて回路の最適値を求めることができる.

\section{$2 \cdot 2$ 直列二重吸振器のモデル 図 5 に圧電素子} と電子回路を用いた直列二重吸振器のモデルを示す. この回路にはインダクタンスが直列に二つ, キャパシ タンスが一つ含まれ，圧電素子内のキャパシタンスと 合わせると電気系が二自由度となる. 図6にこのモデ ルの等価機械モデルを示す ${ }^{(10)}$. 等価機械モデルは機械 式の直列二重動吸振器のモデルと一致する. 機械式の 直列二重動吸振器において, 動吸振器内のダッシュポ ットは一つでよいという知見(9)が得られているが, 図 5 のモデルにおいても必要な抵抗は一つである.

Piezoelectric elements

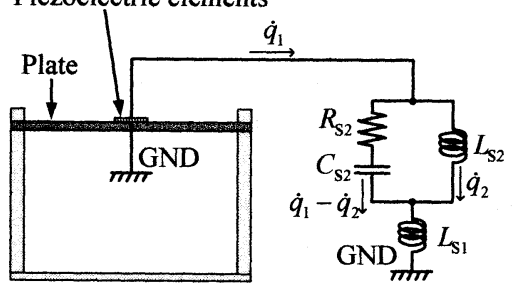

Fig. 5 Model of a dual and series electrical vibration absorber.

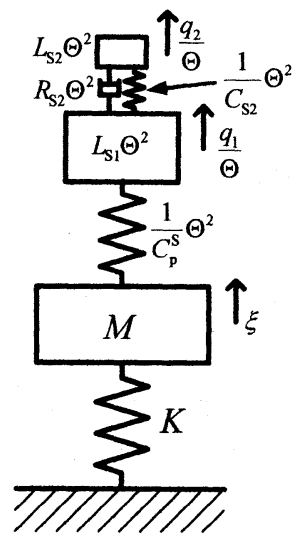

Fig. 6 Equivalent mechanical model for the model of the dual and series electrical vibration absorber.

2-2.1 支屍方程式 図5に示した直列二重吸振 器のモデルの支配方程式は

$$
M \ddot{\xi}+K \xi+\Theta\left(\frac{\Theta}{C_{\mathrm{p}}^{\mathrm{s}}} \xi-\frac{1}{C_{\mathrm{p}}^{\mathrm{s}}} q_{1}\right)=Q P_{\mathrm{f}}
$$

$$
\begin{aligned}
& L_{\mathrm{S} 1} \ddot{q}_{1}+R_{\mathrm{S} 2}\left(\dot{q}_{1}-\dot{q}_{2}\right)+\frac{1}{C_{\mathrm{S} 2}}\left(q_{1}-q_{2}\right) \\
& =\frac{\Theta}{C_{\mathrm{p}}^{\mathrm{s}}} \xi-\frac{1}{C_{\mathrm{p}}^{\mathrm{s}}} q_{1} \\
& L_{\mathrm{S} 2} \ddot{q}_{2}=R_{\mathrm{S} 2}\left(\dot{q}_{1}-\dot{q}_{2}\right)+\frac{1}{C_{\mathrm{S} 2}}\left(q_{1}-q_{2}\right)
\end{aligned}
$$

となる.式(19)-(21)より無次元化したコンプライアンス は

$$
\begin{aligned}
\frac{\xi}{\xi_{\mathrm{st}}} & =\frac{1}{-g^{2}+1+\beta\left(1-G_{\mathrm{C}}\right)} \\
G_{\mathrm{C}} & =\frac{q_{1}}{\Theta \xi} \\
& =\frac{f_{\mathrm{a} 1}^{2}}{-g^{2}+f_{\mathrm{a} 1}^{2}+\left(\mu f_{\mathrm{a} 2}^{2}+2 j \zeta \mu f_{\mathrm{a} 1} g\right)\left(1-G_{\mathrm{D}}\right)} \\
G_{\mathrm{D}} & =\frac{q_{2}}{q_{1}}=\frac{f_{\mathrm{a} 2}^{2}+2 j \zeta f_{\mathrm{a} 1} g}{-g^{2}+f_{\mathrm{a} 2}^{2}+2 j \zeta f_{\mathrm{a} 1} g} \\
\omega_{\mathrm{a} 1} & =\sqrt{\frac{1}{L_{\mathrm{S} 1} C_{\mathrm{p}}^{\mathrm{s}}}, \quad \omega_{\mathrm{a} 2}}=\sqrt{\frac{1}{L_{\mathrm{s} 2} C_{\mathrm{S} 2}}}, \quad \beta=\frac{\Theta^{2}}{K C_{\mathrm{p}}^{\mathrm{s}}} \\
f_{\mathrm{a} 1} & =\frac{\omega_{\mathrm{a} 1}}{\Omega}, \quad f_{\mathrm{a} 2}=\frac{\omega_{\mathrm{a} 2}}{\Omega}, \quad \mu=\frac{L_{\mathrm{s} 2}}{L_{\mathrm{s} 1}} \\
\zeta & =\frac{R_{\mathrm{s} 2}}{R_{\mathrm{s} 0}}, R_{\mathrm{s} 0}=2 L_{\mathrm{s} 2} \sqrt{\frac{1}{L_{\mathrm{s} 1} C_{\mathrm{p}}^{\mathrm{s}}}}
\end{aligned}
$$

となる。

2.2.2 ノミナル取遗調整式 直列二重吸振器の 場合も最適調整式を理論的に導出することは困難であ る. 式(22)-(24)より $f_{\mathrm{a} 1}, f_{\mathrm{a} 2}, \mu, \zeta$ の四つの最適調 整式を求める必要がある. ここで, 式(19)-(21)より支配 方程式は線形であるので，これらの最適調整式は前節 と同様に圧電素子の等価剛性比 $\beta$ のみによって表さ れる. 図 7,8 に数值最適化手法で求めた $f_{\mathrm{a} 1}, f_{\mathrm{a} 2}, \mu$, $\zeta$ の最適值を示す. 図 9 に例として $\beta=0.0004$, $0.004 ， 0.04$ の時にこれらの最適值を用いて求めたコ ンプライアンスを示す.この結果より図 7,8に示した 最適值が有効であることが分かる. $f_{\mathrm{a} 1}, f_{\mathrm{a} 2}, \mu, \zeta$ の最適值を近似式で表すと

$$
\begin{aligned}
& f_{\mathrm{a} 1}=\sqrt{1+1.59 \beta-0.106 \beta^{2}} \\
& f_{\mathrm{a} 2}=\sqrt{1-3.19 \beta+5.36 \beta^{2}} \\
& \mu=2.40 \beta+1.93 \beta^{2} \\
& \zeta=\sqrt{1.18 \beta-6.38 \beta^{2}}
\end{aligned}
$$

となった. 近似式(25)-(28)も決定係数がほぼ 1 であり, 図 7,8 に示したグラフとよく一致する. 等価風性比 $\beta$ は一般に 1 よりも十分に小さいので, 式(27)よりイン ダクタンス比 $\mu$ も 1 より十分小さい. そのため, 圧電 素子に加わる制御電圧は $L_{\mathrm{S} 1}$ の分圧とほぼ等しい. 図 


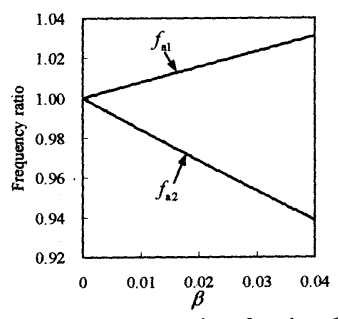

Fig. 7 Optimum frequency ratios for the dual and series electrical vibration absorber.
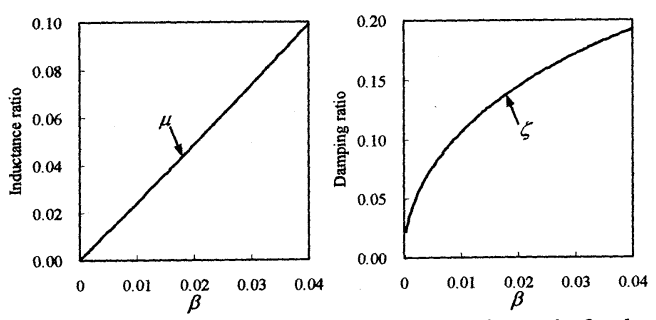

Fig. 8 Optimum inductance ratio and damping ratio for the dual and series electrical vibration absorber.

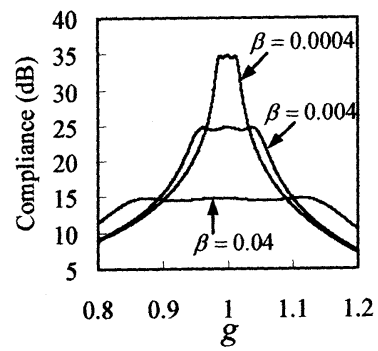

Fig. 9 Calculated results of compliance using the dual and series electrical vibration absorber.

7 より $L_{\mathrm{S} 1}$ と $C_{\mathrm{p}}^{\mathrm{s}}$ からなる共振振動数 $\omega_{\mathrm{a} 1}$ は主系の固有 振動数 $\Omega$ より大きく， $L_{\mathrm{S} 2}$ と $C_{\mathrm{S} 2}$ からなる共振振動数 $\omega_{\mathrm{a} 2}$ は主系の固有振動数 $\Omega$ よりも小さい. また, これ らの共振振動数と主系の固有振動数の差の比はほぼ 1:2である. 回路の最適値は式(25)-(28)より求めること ができる.

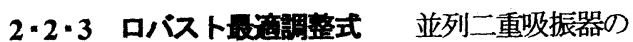
場合と同様に, 主系の剛性の変化を考慮したロバスト 最適調整式を求めた。ここでは代表として $\pm 10 \%$ ， $\pm 20 \%$ の剛性の変化を想定した場合の最適調整式を示 す.

主系の剛性の変化率を $\pm 10 \%$ と想定した場合は

$$
\begin{aligned}
& f_{\mathrm{a} 1}=\sqrt{1.01+2.48 \beta-7.94 \beta^{2}} \\
& f_{\mathrm{a} 2}=\sqrt{0.982-3.35 \beta+6.94 \beta^{2}} \\
& \mu=0.0105+2.96 \beta-3.09 \beta^{2}
\end{aligned}
$$

$$
\zeta=\sqrt{0.00235+1.08 \beta-6.18 \beta^{2}}
$$

となった．また，主系の剛性の変化率を $\pm 20 \%$ と想定 した場合は

$$
\begin{aligned}
& f_{\mathrm{a} 1}=\sqrt{1.03+2.79 \beta-7.30 \beta^{2}} \\
& f_{\mathrm{a} 2}=\sqrt{0.926-2.80 \beta+0.0410 \beta^{2}} \\
& \mu=0.0406+3.14 \beta-2.42 \beta^{2} \\
& \zeta=\sqrt{0.00878+0.893 \beta-5.08 \beta^{2}}
\end{aligned}
$$

であった. 近似式(29)-(36)も決定係数がほぼ 1 であった. 主系の剛性の変化率を大きく見積もるほど， $\omega_{\mathrm{al}}$ は大 きくなり， $\omega_{\mathrm{a} 2}$ は反対に小さくなる. なお， $\beta$ を定数 とすると $f_{\mathrm{a} 1}, f_{\mathrm{a} 2}, \mu, \zeta$ の最適値はいずれも剛性の 変化率を変数とした二次関数上に乗るので, 任意の変 化率での最適值が必要な場合はその性質を利用して式 (25)-(36)より求めればよい.

\section{3. 数值計算と実䀫}

3:1 実験装貫と対象の振動モ一ド 図 10,11 に実験装置と回路の概略を示す。図 11 に示すように制 振対象の平板に性能のほぼ等しい圧電素子を二枚貼り 付け，並列二重吸振器の実験では一枚ずつに LR 回路 を接続し，直列二重吸振器の実験では一枚を直列接続 で一組にして使用した。 なお，二枚の圧電素子を並列 接続で一組にしても, 回路の最適值が異なるのみで直 列二重吸振器の制振性能は等しい。平板 $(300 \times 400 \times 1.0 \mathrm{~mm})$ はアルミニウム製で周辺を固定し，

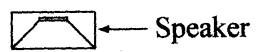

Sound pressure excitation $+1+1$

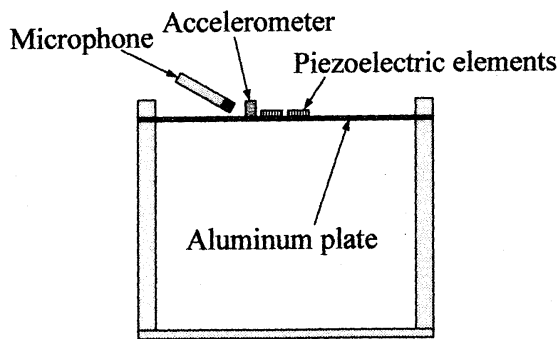

Fig. 10 Schematic diagram of the experimental apparatus.

Dual and series DVA Dual and parallel DVA
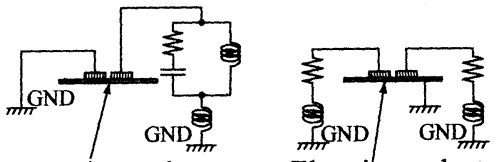

Electric conductor Electric conductor Fig. 11 Schematic diagram of the circuits. 
圧電素子 $(22 \times 32 \times 0.22 \mathrm{~mm})$ は導電性接着剤で貼り付 けた. 制振対象は固有振動数が約 $80 \mathrm{~Hz}$ の基本振動モ 一ドとした. 圧電素子の等価剛性比は対象とする振動 モードの曲率最大の位置に貼り付けると最も大きくな るので，圧電素子は平板の中央に貼り付けた． $L_{\mathrm{S} 2}$ に はコイルを使用し，それ以外のインダクタンスには Generalized Impedance Converterによる合成可変インダ クタンスを用いた ${ }^{(11)} . L_{\mathrm{s} 2}$ 以外のインダクタンスをコ イルにするとそのサイズが非常に大きくなるためであ る.

3-2 実䄼方法 図 10 のように平板を音圧で加振 し，加速度ピックアップとマイクロフォンで平板の振 動変位と加振音圧を測定した. ここで, 加速度ピック アップは $(x, y)=(0.15 \mathrm{~m}, 0.15 \mathrm{~m})$ の位置に設置した.

図 12 に座標軸の取り方を示す。 $z$ は平板の中立面から の距離である.マイクロフォンは $(x, y, z)=(0.15 \mathrm{~m}, 0.10 \mathrm{~m}, 0.01 \mathrm{~m})$ の位置に設置した. 加振音圧と振動変位より無次元化したコンプライアン スを求めた.

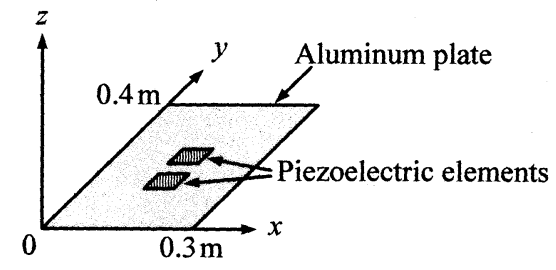

Fig. 12 Coordinates of a plate.

3-3 数値計算と実検の結果 表 1 亿数値計算で 用いた平板と圧電素子の諸元を示す。これらは全て実 験で使用した装置の実測値である(12)。二枚の圧電素子 は大きさと材質が等しいものを平板の左右対称の位置 に貼り付けて用いたが，表 1 のように実測した等価剛

Table 1 Values of material parameters.

\begin{tabular}{c|c|rl}
\hline \multirow{2}{*}{ Plate } & $M$ & 1.000 & $\mathrm{~kg}$ \\
\cline { 2 - 4 } & $K$ & 250800 & $\mathrm{~N} / \mathrm{m}$ \\
\hline \multirow{3}{*}{$\begin{array}{c}\text { Piezo } \\
\text { (Total) }\end{array}$} & $C_{\mathrm{p}}^{\mathrm{s}}$ & 0.0219 & $\mu \mathrm{F}$ \\
\cline { 2 - 4 } & $\Theta$ & 0.00344 & $\mathrm{~N} / \mathrm{V}$ \\
\cline { 2 - 4 } & $\beta$ & 0.00215 & \\
\hline \multirow{3}{*}{$\begin{array}{c}\text { Piezo } \\
\text { (No. 1) }\end{array}$} & $C_{\mathrm{pl}}^{\mathrm{S}}$ & 0.0411 & $\mu \mathrm{F}$ \\
\cline { 2 - 4 } & $\Theta_{1}$ & 0.00357 & $\mathrm{~N} / \mathrm{V}$ \\
\cline { 2 - 4 } & $\beta_{1}$ & 0.00123 & \\
\hline \multirow{3}{*}{$\begin{array}{c}\text { Piezo } \\
\text { (No. 2) }\end{array}$} & $C_{\mathrm{p} 2}^{\mathrm{s}}$ & 0.0398 & $\mu \mathrm{F}$ \\
\cline { 2 - 4 } & $\Theta_{2}$ & 0.00308 & $\mathrm{~N} / \mathrm{V}$ \\
\cline { 2 - 4 } & $\beta_{2}$ & 0.000945 \\
\hline
\end{tabular}

性比等の值には少し差があった．以下の数値計算では 二枚の圧電素子を一組にした場合の諸元を使用し，並 列二重吸振器でも等分割を仮定して回路の最適值を求

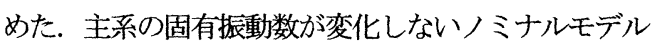
での数值計算と実験の結果と, 主系の固有振動数が変 化する場合の数值計算と実験の結果を以下に示す.

\section{3·3・1 ノミナル最棓調整での結果 図 13 に一} 重吸振器, 並列二重吸振器, 直列二重吸振器をノミナ ル最適調整式にもとづいて設計した場合の数值計算結 果を示す.ここで, 一重吸振器と二重吸振器の制振性 能を実線と破線で示した. 直列二重吸振器の制振性能 が最も高く, 一重吸振器の制振性能が最も低い. 図 14 にこれらの数值計算結果に相当する実験結果を示す. また, 表 2 に並列二重吸振器と直列二重吸振器の数值 計算と実験での回路の值を合わせて示す.ここで, 数 値計算で使用した回路の値は，二章で求めた最適調整 式を用いて求めた，実験では平板自体に減衰が含まれ るため, 数值計算結果に比べて実験結果では三つの手 法の制振性能の差は小さいが，傾向は一致している. 回路の值も数值計算と実験で概ね一致しており, 前章 で求めたノミナル最適調整式の有効性が確認できる.

\section{3·3・2 ロパスト最調整での結果制振装置の} ロバスト性を検証するための数値計算と実験を行った. ここでは主系の剛性の変化を $\pm 5 \%$ と想定して, 回路を 調整した。なお, 実験では平板上の点 $(x, y)=(0.10 \mathrm{~m}, 0.20 \mathrm{~m})$ の周辺に質量を付加すること で主系の固有振動数を $70 \mathrm{~Hz}$ から $78 \mathrm{~Hz}$ まで $2 \mathrm{~Hz}$ 刻みで 変化させた. そのため, 主系の固有振動数が $74 \mathrm{~Hz}$ の 場合を中心として回路の調整を行った. ここで, 固有 振動数が $72 \mathrm{~Hz}$ と $76 \mathrm{~Hz}$ の場合はほぼロバスト最適調整 の範用内であり, $70 \mathrm{~Hz}$ と $78 \mathrm{~Hz}$ の場合は範用外である. 図 15 にロバスト最適調整式を用いた場合の, 図 16 に ノミナル最適調整式を用いた場合の数値計算結果を示 す.一重吸振器よりも二重吸振器のロバスト性能が高 いことと，ロバスト最適調整式の有効性が確認できる. また，ロバスト最適調整を行った場合でも主系の固有 振動数が $70 \mathrm{~Hz}$ や $78 \mathrm{~Hz}$ の場合のように, 想定する剛性 変化の範用外では制振性能が低下することが分かる.

図 17 にロバスト最適調整式にもとづいて回路を設計 した場合の実験結果を示す。また, 表 3 にロバスト最 適調整を行った場合の数値計算と実験での回路の值を 合わせて示す. 実駼結果でも二重吸振器のロバスト性 能の高さが確認できる. また, 回路の值も数值計算と 実験で概ね一致しており, 前章で求めたロバスト最適 調整式の有効性が確認できる. 

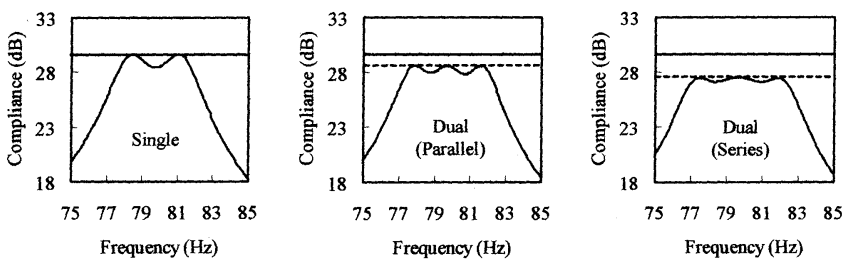

Fig. 13 Calculated results of compliance.
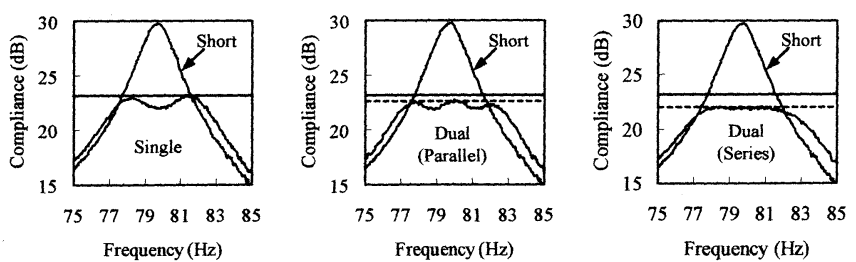

Fig. 14 Experimental results of compliance.
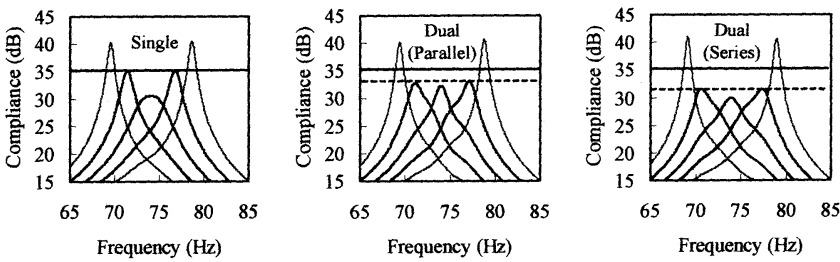

Fig. 15 Calculated results of compliance with considering robustness.
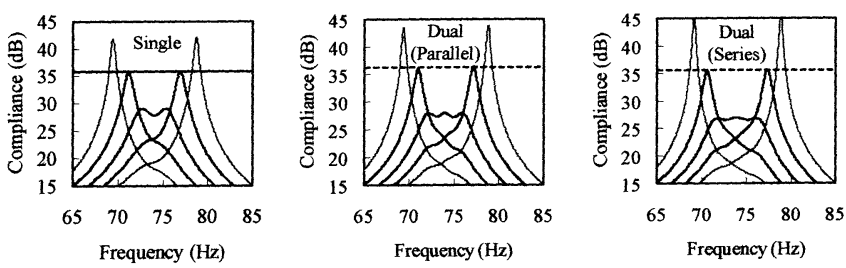

Fig. 16 Calculated results of compliance without considering robustness.
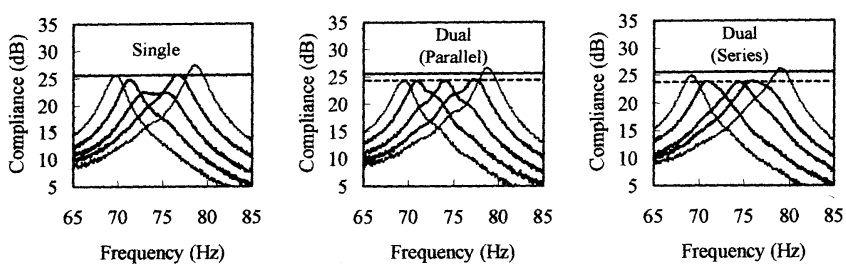

Fig. 17 Experimental results of compliance with considering robustness.
Table 2 Values of circuits of the electrical dual vibration absorbers in nominal models.

\begin{tabular}{c|c|c}
\hline & Cal. & Exp. \\
\hline$L_{\mathrm{p} 1}$ & $88.5 \mathrm{H}$ & $92.7 \mathrm{H}$ \\
\hline$R_{\mathrm{P} 1}$ & $1670 \Omega$ & $1120 \Omega$ \\
\hline$C_{\mathrm{p} 1}^{\mathrm{s}}$ & $0.0438 \mu \mathrm{F}$ & $0.0411 \mu \mathrm{F}$ \\
\hline$\omega_{\mathrm{A} 1}$ & $508 \mathrm{rad} / \mathrm{s}$ & $512 \mathrm{rad} / \mathrm{s}$ \\
\hline$L_{\mathrm{P} 2}$ & $93.5 \mathrm{H}$ & $103 \mathrm{H}$ \\
\hline$R_{\mathrm{p} 2}$ & $1790 \Omega$ & $1270 \Omega$ \\
\hline$C_{\mathrm{p} 2}^{\mathrm{s}}$ & $0.0438 \mu \mathrm{F}$ & $0.0398 \mu \mathrm{F}$ \\
\hline$\omega_{\mathrm{A} 2}$ & $494 \mathrm{rad} / \mathrm{s}$ & $494 \mathrm{rad} / \mathrm{s}$ \\
\hline$L_{\mathrm{S} 1}$ & $181 \mathrm{H}$ & $179 \mathrm{H}$ \\
\hline$C_{\mathrm{p}}^{\mathrm{s}}$ & $0.0219 \mu \mathrm{F}$ & $0.0219 \mu \mathrm{F}$ \\
\hline$\omega_{\mathrm{a} 1}$ & $502 \mathrm{rad} / \mathrm{s}$ & $505 \mathrm{rad} / \mathrm{s}$ \\
\hline$L_{\mathrm{S} 2}$ & $0.940 \mathrm{H}$ & $1.04 \mathrm{H}$ \\
\hline$R_{\mathrm{S} 2}$ & $47.2 \Omega$ & $59.6 \Omega$ \\
\hline$C_{\mathrm{S} 2}$ & $4.27 \mu \mathrm{F}$ & $3.97 \mu \mathrm{F}$ \\
\hline$\omega_{\mathrm{a} 2}$ & $499 \mathrm{rad} / \mathrm{s}$ & $492 \mathrm{rad} / \mathrm{s}$ \\
\hline & &
\end{tabular}

Table 3 Values of circuits of the electrical dual vibration absorbers with considering robustness.

\begin{tabular}{c|c|c}
\hline & Cal. & Exp. \\
\hline$L_{\mathrm{p} 1}$ & $100 \mathrm{H}$ & $107 \mathrm{H}$ \\
\hline$R_{\mathrm{p} 1}$ & $2340 \Omega$ & $1540 \Omega$ \\
\hline$C_{\mathrm{p} 1}^{\mathrm{S}}$ & $0.0438 \mu \mathrm{F}$ & $0.0411 \mu \mathrm{F}$ \\
\hline$\omega_{\mathrm{A} 1}$ & $478 \mathrm{rad} / \mathrm{s}$ & $477 \mathrm{rad} / \mathrm{s}$ \\
\hline$L_{\mathrm{P} 2}$ & $111 \mathrm{H}$ & $122 \mathrm{H}$ \\
\hline$R_{\mathrm{P} 2}$ & $2730 \Omega$ & $1650 \Omega$ \\
\hline$C_{\mathrm{p} 2}^{\mathrm{s}}$ & $0.0438 \mu \mathrm{F}$ & $0.0398 \mu \mathrm{F}$ \\
\hline$\omega_{\mathrm{A} 2}$ & $454 \mathrm{rad} / \mathrm{s}$ & $454 \mathrm{rad} / \mathrm{s}$ \\
\hline$L_{\mathrm{S} 1}$ & $209 \mathrm{H}$ & $207 \mathrm{H}$ \\
\hline$C_{\mathrm{p}}^{\mathrm{s}}$ & $0.0219 \mu \mathrm{F}$ & $0.0219 \mu \mathrm{F}$ \\
\hline$\omega_{\mathrm{a} 1}$ & $467 \mathrm{rad} / \mathrm{s}$ & $470 \mathrm{rad} / \mathrm{s}$ \\
\hline$L_{\mathrm{S} 2}$ & $2.01 \mathrm{H}$ & $1.88 \mathrm{H}$ \\
\hline$R_{\mathrm{S} 2}$ & $113 \Omega$ & $85.9 \Omega$ \\
\hline$C_{\mathrm{S} 2}$ & $2.33 \mu \mathrm{F}$ & $2.44 \mu \mathrm{F}$ \\
\hline$\omega_{\mathrm{a} 2}$ & $462 \mathrm{rad} / \mathrm{s}$ & $467 \mathrm{rad} / \mathrm{s}$ \\
\hline
\end{tabular}




\section{4. 結 言}

圧電素子と電子回路を用いた装置で, 機械式の二重 動吸振器に相当するモデルを示した. 機械式の二重動 吸振器には並列型と直列型があり，本論文ではその両 方に相当するモデルを提案した. 数值計算と実験を行 い,ノミナルモデルで回路を最適に調整した場合は直 列二重動吸振器に相当する回路の制振性能が高く, 主 系の固有振動数の変化を考慮して回路の調整を行った 場合は並列型, 直列型ともに従来の一重動吸振器に相 当する回路よりもロバスト性が高いことを示した.

\section{謝 辞}

本研究は日本学術振興会の科学研究費補助金 (特別 研究員奨励費, 課題番号 18・2836）の助成を受けたこ とを付記し，謝意を表する.

\section{文献}

(1) Forward, R. L., Applied Optics, Vol. 18, №. 5 (1979), pp. 690-697.

(2) Dosch, J. J., and Inman, D. J., Journal of Intelligent Material Systems and Structures, Vol. 3, (1992), pp. 166-185.

(3) Hagood, N. W. and Flotow, A. V., Journal of Sound and Vibration, Vol. 146, No. 2 (1991), pp. 243-268.

(4) Park, C. H. and Inman, D. J., Proceeding of SPIE Smart Structures and Materials 1999: Smart Structures and Integrated Systems, Vol. 3668, part two, (1999), pp. 797-804.

(5) Yamada, K. et al., Journal of the Japan Society of Mechanical Engineers, Series C, Vol. 71, No. 707 (2005), pp. 2187-2194.

(6) Wu, S. Y., Journal of Intelligent Material Systems and Structures, Vol. 9, (1998), pp. 991-998.

(7) Ho, S. T. et al., Journal of the Japan Society of Mechanical Engineers, Series C, Vol. 66, No. 643 (2000), pp. 737-743.

(8) Iwanami, K. et al., Journal of the Japan Society of Mechanical Engineers, Series C, Vol. 50, No. 449 (1984), pp. 44-51.

(9) Pan, G et al., Journal of the Japan Society of Mechanical Engineers, Series C, Vol. 71, No. 712 (2005), pp. 3430-3436.

(10) Yamada, K. et al., Dynamic and Design Conference 2006, CD-ROM, No. 627 (2006), pp. 1-6.

(11) Hori, T., Design Method of the Circuit of Analogue
Filter (in Japanese), (1998), pp. 154-156, Sogo Denshi Shuppan.

(12) Yamada, K. et al., Journal of the Japan Society of Mechanical Engineers, Series C, Vol. 71, No. 710 (2005), pp. 2896-2903. 